\title{
Patchy charnockites from Jenapore, Eastern Ghats granulite belt, India: Structural and petrochemical evidences attesting to their relict nature
}

\author{
RAJIB KAR* \\ Geological Studies Unit, Indian Statistical Institute, 203 B. T. Road, Calcutta 700 035, India. \\ e-mail: rajib_kar@hotmail.com \\ * Present address: Department of Geology, J. K. College, Purulia 723 101, West Bengal, India.
}

\begin{abstract}
The charnockite patches that occur within leptynite host, in and around Jenapore, northern sector of the Eastern Ghats granulite belt, are disposed in a linear fashion and generally have sharp lithological contact with the host leptynite. Sometimes the patches and foliations of the host are cofolded. Also, the patches sometimes have the internal $S_{1}$ foliation, while the host leptynite records only $S_{2}$ foliation. Mineralogically and chemically patchy charnockites and host leptynites are distinct entities, and cannot be related by any prograde and retrograde reactions. Particularly important is the peraluminous granitic composition and high $\mathrm{Rb} / \mathrm{Sr}$ ratios of the leptynites, presumably resulting from biotite-dehydration melting; as against metaluminous granodioritic to tonalitic composition and low $\mathrm{Rb} / \mathrm{Sr}$ ratios of the patchy charnockites, presumably resulting from hornblende-dehydration melting. The charnockite patches here can be interpreted as caught up patches or xenolith within granitic melt (leptynite). Mg-rich rims of garnet in the charnockite patch were probably caused by heat from the crystallising melt or decompression during ascent of melt.
\end{abstract}

\section{Introduction}

Charnockitic rocks are important constituents of high grade terrains, and could have originated by both igneous and metamorphic processes (Newton 1992a). From its type area, near Pallavaram, Madras (presently Chennai), Holland (1893, 1900) first suggested a plutonic igneous origin of the charnockite. Later on, Howie (1955) elaborated this idea and proposed the concept of plutonic metamorphism, according to which charnockitic magma was emplaced at lower crustal depths. Pichamuthu (1960) first described 'patchy charnockites' within host amphibolite facies gneisses from Kabbaldurga, Karnataka, south India, and interpreted them as arrested growth from the host. Subsequently, many workers suggested that the "patchy charnockites' from several places in south India are products of in situ metamorphic transfor- mation or 'charnockitisation' (Janardhan et al 1979; Hansen et al 1987a, b; Stahle 1987; Newton 1992b). Some workers even interpreted the larger charnockite bodies as products of 'progressive charnockitisation' (Raith et al 1990; Srikantappa et al 1992; Janardhan et al 1994; Harley and Santosh 1995; Janardhan and Francis 1996).

These diverse petrogenetic interpretations or models for the origin of charnockitic rocks are based primarily on petrological observations; the structural setting of these rocks, are, in many cases, not well documented. In this context it is important to note that from some south Indian localities Naha (1988) and Naha et al (1993) described charnockitic rocks that occur in a variety of different structural setting and differ in style and time relation.

Keywords. Patchy charnockite; leptynite; distinct entities; relict. 
Also, in the Eastern Ghats granulite belt, India, the charnockitic rocks occur in different modes, namely, as larger massif-type bodies and as patches in the host leptynitic gneisses (Bhattacharya et al 1993a, 1994; Rao et al 1995; SubbaRao et al 1995; Kar 1995). Several workers have assumed an in situ transformation origin for the patchy charnockites (Aftalion et al 1988; Paul et al 1990), but Bhattacharya et al (1993a, 1994) described the relict nature of the patchy charnockites from the Chilka Lake area. Recently, Dobmeier and Raith (2000) presented an alternative interpretation - "arrested growth" for the patchy charnockites of the Chilka Lake area. This is one of the leading controversies, and for a proper resolution of this issue, many more specific examples should be investigated. The present communication deals with a case of patchy charnockite from the northern sector of the Eastern Ghats belt.

The charnockitic rocks here occur in two different modes. One variety occurs as large massif-type bodies associated with minor bands and lenses of enderbite, two-pyroxene granulite and hornblendebearing mafic granulites. The other variety occurs as patches within leptynitic gneisses. It can be shown on the basis of field-structural and petrological data that, the massif-type charnockite is a product of hornblende-dehydration melting in the protolith of hornblende-bearing mafic granulite and the associated two-pyroxene granulite and enderbite are cumulates of solid peritectic phases, equilibrating with the charnockitic melt (Kar et al 2000).

Any scientific discussion of charnockitic rocks should take into account its nomenclature. Holland (1900) first defined the charnockite as orthopyroxene-bearing granite, found abundantly in south India, with the conviction that they are of plutonic igneous origin. Later on, Streckeisen (1976) also subdivided the orthopyroxene bearing quartzo-feldspathic rocks into charnockite, farsundite, charno-enderbite and enderbite, with the assumption that they are plutonic rocks. On the other hand, in his review paper Newton (1992a) noted that many of the south Indian charnockitic rocks are poor in K-feldspar, corresponding to granodiorite or quartz monzonite, rather than granite, in mineralogy. He also pointed out that these rocks are complexly foliated, interlayered with various metasediments, and some contain garnet and even graphite, and are definitely metamorphic in origin. For these reasons, he suggested that it is better to adopt Pichamuthu's (1969) most general and non-genetic definition of charnockite as any quartzo-feldspathic rocks with orthopyroxene. Some Indian workers (Bhattacharya et al 1993a; Sen and Bhattacharya 1993) and workers from else- where also use the term charnockite in a similar manner (De Waard 1969; Ridley 1992; Kilpatrick and Ellis 1992). It is also important to note that the natural occurrence of charnockitic rocks includes intimately associated varieties that may be termed charnockite, charno-enderbite and enderbite.

\section{Geological setting}

Besides the presence of the massif-type charnockite suite of rocks in the study area, metapelitic granulites and orthopyroxene-free granites are also important lithologies. Metapelitic granulites are primarily of two types, namely, khondalite and quartzite. Quartzite occur as minor bands within khondalite. On the other hand, orthopyroxene-free granites are principally of three types, namely, leptynite, leucogranite and porphyritic granite-gneiss. The definition of dominant lithologies is presented in table 1.

Three phases of folding are recorded from the study area (Kar 1995). Large massif-type charnockite and khondalite are characterised by the presence of streaky gneissic foliation and pervasive gneissosity respectively. Minor quartzite bands in the khondalite host and hornblende-bearing mafic granulite bands in the charnockite host define reclined, intrafolial $F_{1}$ folds. The gneissic foliations of the hosts are axial planar to these folds, and hence designated as $S_{1}$ fabric. $F_{2}$ folds, fairly tight, commonly developed on these $S_{1}$ fabrics and have axial planar leptynitic foliation in both the khondalite and massif-type charnockite. Hence the leptynitic foliation is designated as $S_{2}$ fabric. $F_{2}$ folds commonly occur on a mappable scale. Except the mesoscopic $F_{2}$ fold hinges, $S_{1}$ fabric is parallel to $S_{2}$ fabric on a regional scale. The composite $S_{1} \| S_{2}$ fabric defines broad $F_{3}$ warps. This three-phase folding history is correlatable to those described from the other areas in the Eastern Ghats (Halden et al 1982; Bhattacharya et al 1994; Shaw 1996).

Orthopyroxene-free granites generally occur as minor stock-like bodies at the core of the mapable $F_{2}$ folds in the charnockite and khondalite host (figure 1, insets A \& B). The foliations present in them, i.e., leptynitic foliation in leptynite and leucogranite passes undeviated into adjacent charnockite and khondalite, and is axial planar to $F_{2}$ folds, and hence this foliation is designated as $S_{2}$. Similarly, the gneissic foliation in porphyritic granite is parallel to the axial plane of the mesoscopic $F_{2}$ fold in the host charnockite and/or khondalite, and hence it is also designated as $S_{2}$.

On the other hand, dismembered charnockite patches are generally disposed in a linear fashion within the leptynitic host (figure 2). Notably, 
Table 1. Definition of different rock types used in the text.

\begin{tabular}{ll}
\hline Charnockite & $\begin{array}{l}\text { Quartzo-feldspathic rock with orthopyroxene as essential mineral phase; } \\
\text { minor clinopyroxene and garnet also present. } \\
\text { Khondalite }\end{array}$ \\
$\begin{array}{l}\text { Quartz-rich rock with alkali feldspar, sillimanite and garnet as essential } \\
\text { mineral phases. }\end{array}$ \\
Quartzo-feldspathic rock with plattung structure; biotite and garnet are \\
common ferromagnesian phase. \\
Quartzo-feldspathic rock with plattung structure, with minor or no ferro- \\
Leucogranite & $\begin{array}{l}\text { magnesian phases. } \\
\text { Granite with common porphyritic texture; alkali feldspar megacrysts and } \\
\text { biotite rich foliation swerves around it. }\end{array}$ \\
\hline
\end{tabular}

Note: Plattung structure - Platy granoblastic texture, as defined by Mehr (1962) and Sen (1987).

boundaries between them are very sharp. On a closer look, a few significant features can be noted.

- Foliation of the host leptynite swerves around the charnockite patches, with internal foliation (figure 3).

- Foliation of the host leptynite abuts against the charnockite patch.

- The charnockite patches are often folded and the foliation of the host leptynite is parallel to the axial plane of these folds (figure 4).

These features indicate the pre-existing nature of the charnockite patches in the host. In other words, the charnockite patches are enclave in host leptynite.

Porphyritic granite-gneiss also contains enclaves of charnockite with internal foliation, and the foliation of the host swerves around the charnockite patch. Also, the porphyritic granite veins are commonly found to inject the charnockite. These veins are also ptygmatically folded. Furthermore, in the leucogranite host, dismembered charnockite patches are tightly folded with axial planar leptynitic foliation. Sometimes the leptynitic foliation of the host leucogranite is found to also overprint the charnockite patch. All these features collectively suggest the relict nature of the charnockite patches.

The only foliation present in the leptynite, leucogranite and porphyritic granite is designated as $S_{2}$, hence the internal foliation of the relict charnockite patches is pre- $S_{2}$, and probably $S_{1}$. Moreover, the folds defined by the patchy charnockites within leptynite and leucogranite host (figure 4) can be designated as $F_{2}$ folds. Additionally, the ptygmatic fold defined by porphyritic granite is also an $F_{2}$ fold.

\section{Petrography}

\subsection{Orthopyroxene-free granite}

The orthopyroxene-free granites are mainly composed of quartz, alkali feldspar and plagioclase feldspar (table 2). Alkali feldspar largely dominates over plagioclase feldspar. Hence, they are plotted in field 3 (granite) in the modal Q-A-P diagram (figure 5), after Streckeisen (1976). Perthite is very common. Biotite, ilmenite and garnet are common mafic minerals. Occasionally sillimanite trails are present as included phases within garnet. Traces of hornblende have also been noticed. Mafic minerals never exceed $10 \%$ by volume. Zircon is the common accessory.

Quartzo-feldspathic matrix in leptynite and leucogranite are also characterised by relatively fine-grained, polycrystalline, elongate quartz and feldspar with irregular grain boundaries. Occasionally, reduction of grain boundary area to minimize surface free energy resulted in a typical platy granoblastic texture, plattung structure (Mehr 1962 and Sen 1987). Macroscopically, this foliation is manifested as typical leptynitic foliation. On the other hand, in the porphyritic granite, large megacrysts of $\mathrm{K}$ feldspar are embedded in a groundmass of relatively fine-grained quartz and feldspar. Occasionally, in the biotite rich domains, swerving of foliation, defined by biotite flakes, around the K-feldspar megacrysts, is noticed. In overall appearance it looks like a magmatic foliation.

\subsection{Patchy charnockite}

Patchy charnockites of the present area are mainly composed of quartz, plagioclase feldspar and alkali feldspar (table 3). Orthopyroxene is the principal ferromagnesian phase, although garnet is also common. Clinopyroxene and hornblende are present in minor quantities. Plagioclase largely dominates over alkali feldspar in most of the patches (figure 5). Notably, the present samples of patchy charnockites are mafic rich $(>15 \%)$ and are distinct from the host, which contains less than $10 \%$ by volume of mafic minerals (figure 6). 


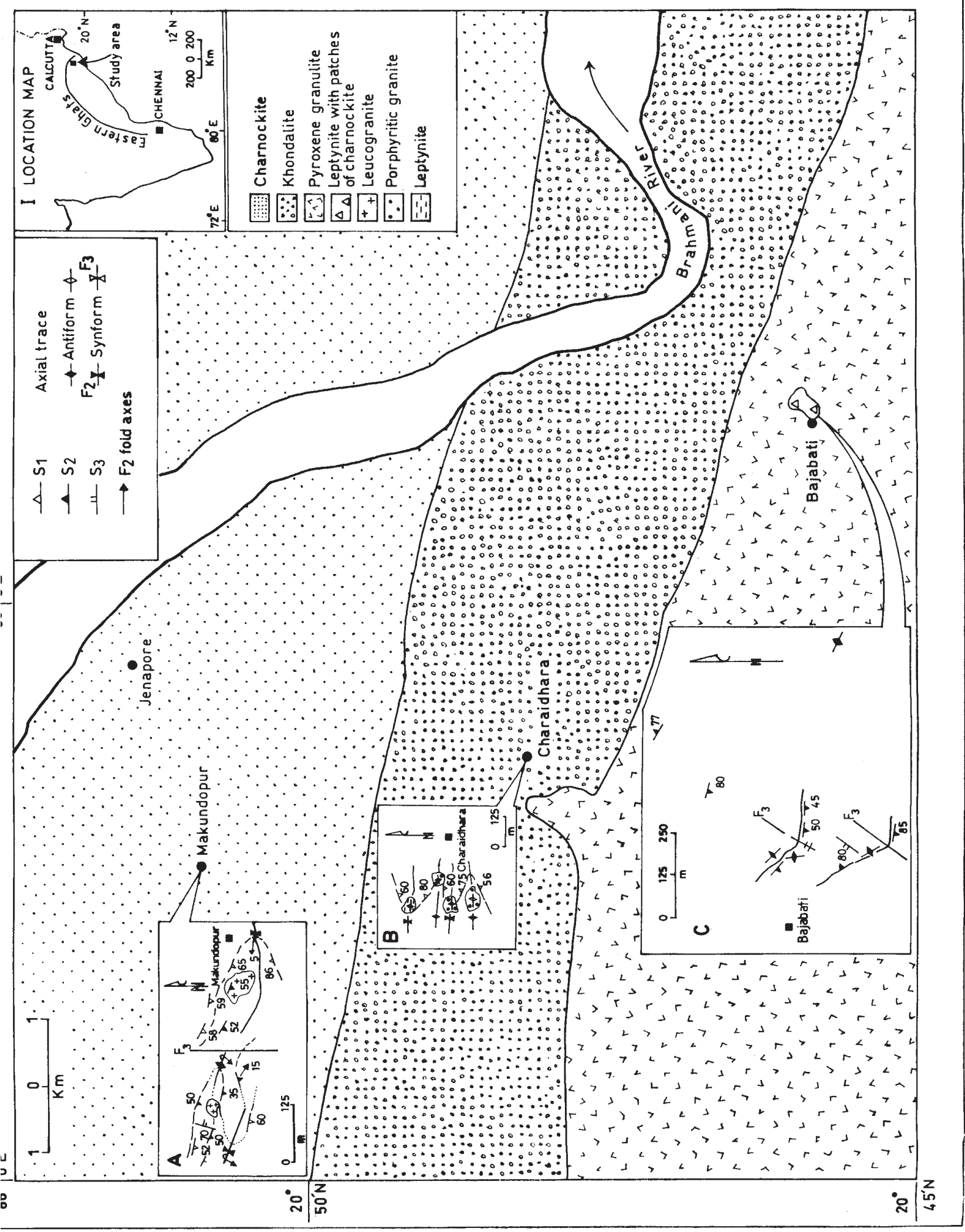


Sharp grain-grain contact with common triple junction (typical granoblastic texture) is the frequently observed texture in the charnockite patches. However, in some samples, microscale gneissic banding, defined by alternate layers of mafic and felsic minerals, was noticed. In fact, this gneissosity defines the internal foliation of the charnockite patches on a mesoscopic scale.

\subsection{Host leptynite}

The host leptynites are strictly granitic in composition, with a high alkali feldspar/plagioclase ratio (table 3 ). Perthite is also common. Garnet and biotite are the common mafic minerals. A notable feature is the variable proportion of garnet and biotite. Zircon is the common accessory. Garnet xenoblasts commonly contain sillimanite inclusion trails. Biotite occurs in two different modes. One is commonly found to corrode the garnet margin. Occasionally this mode of biotites is found to separate garnet xenoblast and alkali feldspar, and can be interpreted as retrograde phase, after garnet. The other mode of biotite grains is an included phase within garnet xenoblasts.

Similar to the other granites, the host leptynites are also characterised by the presence of plattung structure, as manifested by the preferred alignment of relatively finegrained, polycrystalline elongate quartz and feldspar with irregular grain boundaries. In biotite rich domains a typical gneissic foliation results, which enhances the plattung structure.

\section{Geochemistry}

\subsection{Bulk chemistry}

Two pairs of charnockite patches and host leptynite (as given in table 3) were selected for bulk chemical analysis. The chemical analyses for whole rock compositions was done by X-ray Fluorescence Spectrometry at the Wadia Institute of Himalayan Geology, Dehradun. The bulk chemical data are presented in table 4.

Host leptynites are characterised by high normative orthoclase $(34.11,32.70)$ and low normative anorthite $(7.60,8.90)$, which is reflected in the

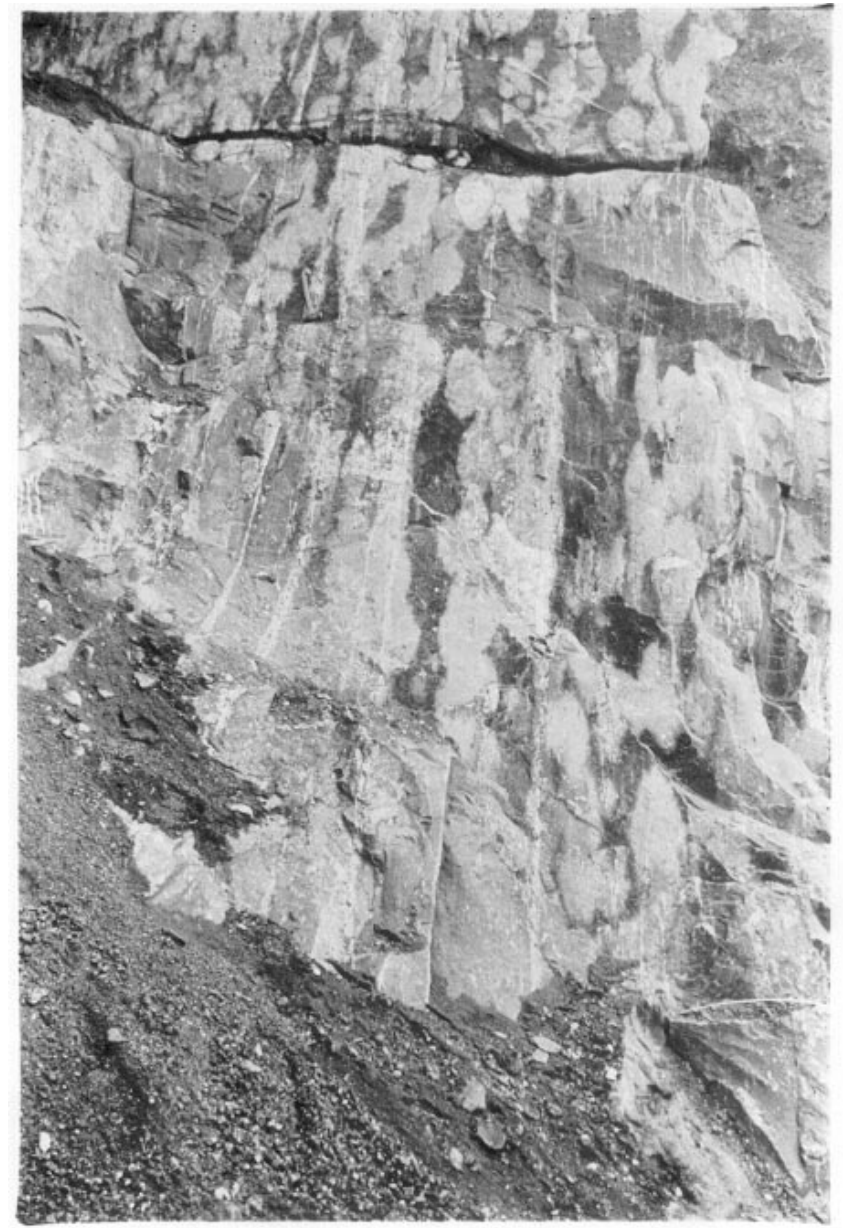

Figure 2. Patches of charnockitic rocks in leptynitic host, disposed in a linear fashion.

high modal abundance of alkali feldspar (table 3). In terms of normative Ab-An-Or proportions (figure 7), after Le Maitre (1989), the compositions of the leptynites can be described as granite sensostricto. Additionally, the leptynites are peraluminous granites with a little normative corundum $(1.28,0.95)$ and an alumina saturation index (A/CNK) greater than unity $(1.08,1.04)$. This marginally peraluminous character is reflected in the presence of aluminous garnet and/or biotite in addition to feldspars. In trace element chemistry, the leptynites are depleted in transitional trace elements $(\mathrm{Cr}, \mathrm{Ni})$ and base metals $(\mathrm{Zn}, \mathrm{Cu})$ and are enriched in $\mathrm{Y}$, Th, $\mathrm{Ba}$ and $\mathrm{Pb}$. Also, they are depleted in Ti. It is important to note that the leptynites have a high $\mathrm{Rb} / \mathrm{Sr}$ ratio (1.17, $1.45)$.

\footnotetext{
Figure 1 caption.

Lithological map of the area in and around Jenapore. Insets depict some important field relations. Inset A: Minor stocks of leucogranite are emplaced along the core of the $F_{2}$ folds in massif-type charnockite. Note the foliation in leucogranite $\left(S_{2}\right)$ passes undeviated into the host charnockite massif and parallel to the $S_{2}$ foliation of the host. Inset B: Minor stocks of porphyritic granite and leptynite are emplaced along the core of the $F_{2}$ folds in khondalite. Inset C: $S_{2}$ foliation of the leptynite with patches of charnockite shows $F_{3}$ fold. Inset I: Location of the study area.
} 


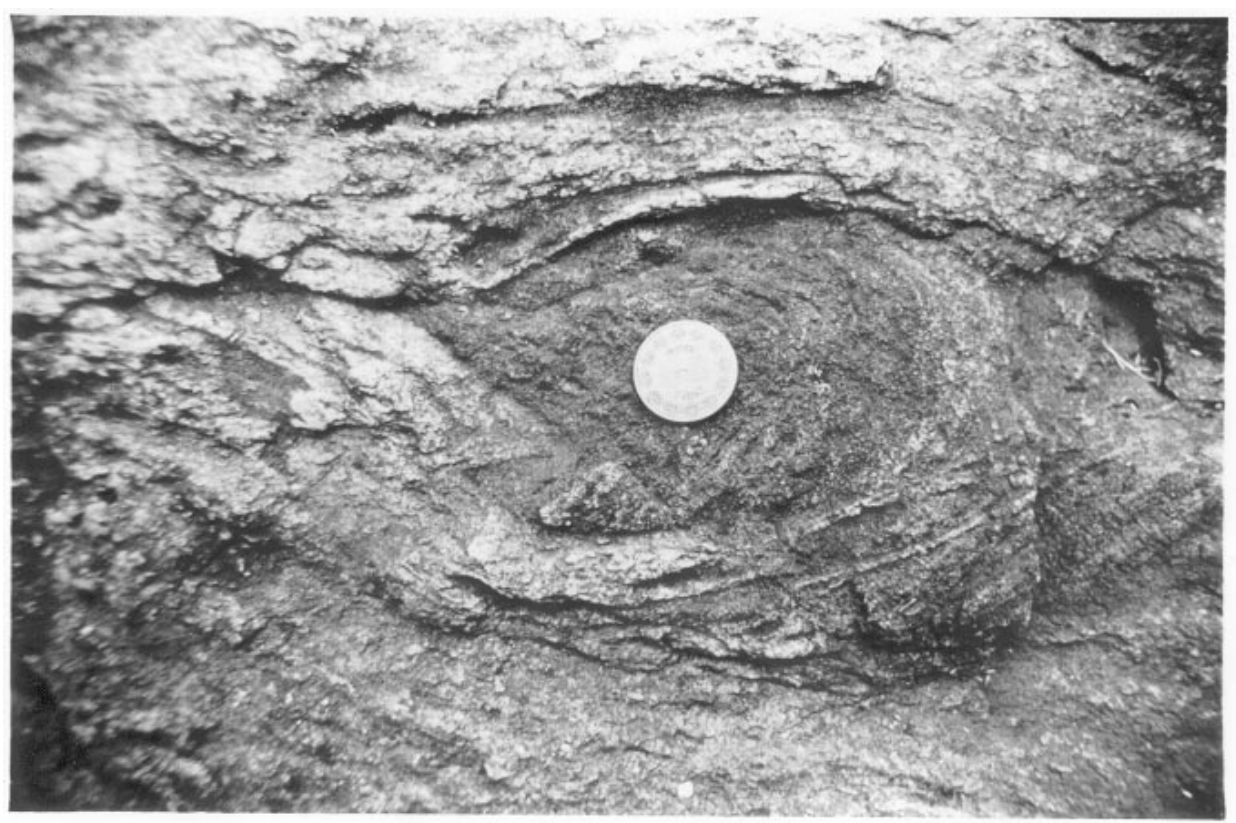

Figure 3. Charnockite patch, with internal foliation $\left(S_{1}\right)$ in leptynitic host; foliation of the host $\left(S_{2}\right)$ swerves around the patch.

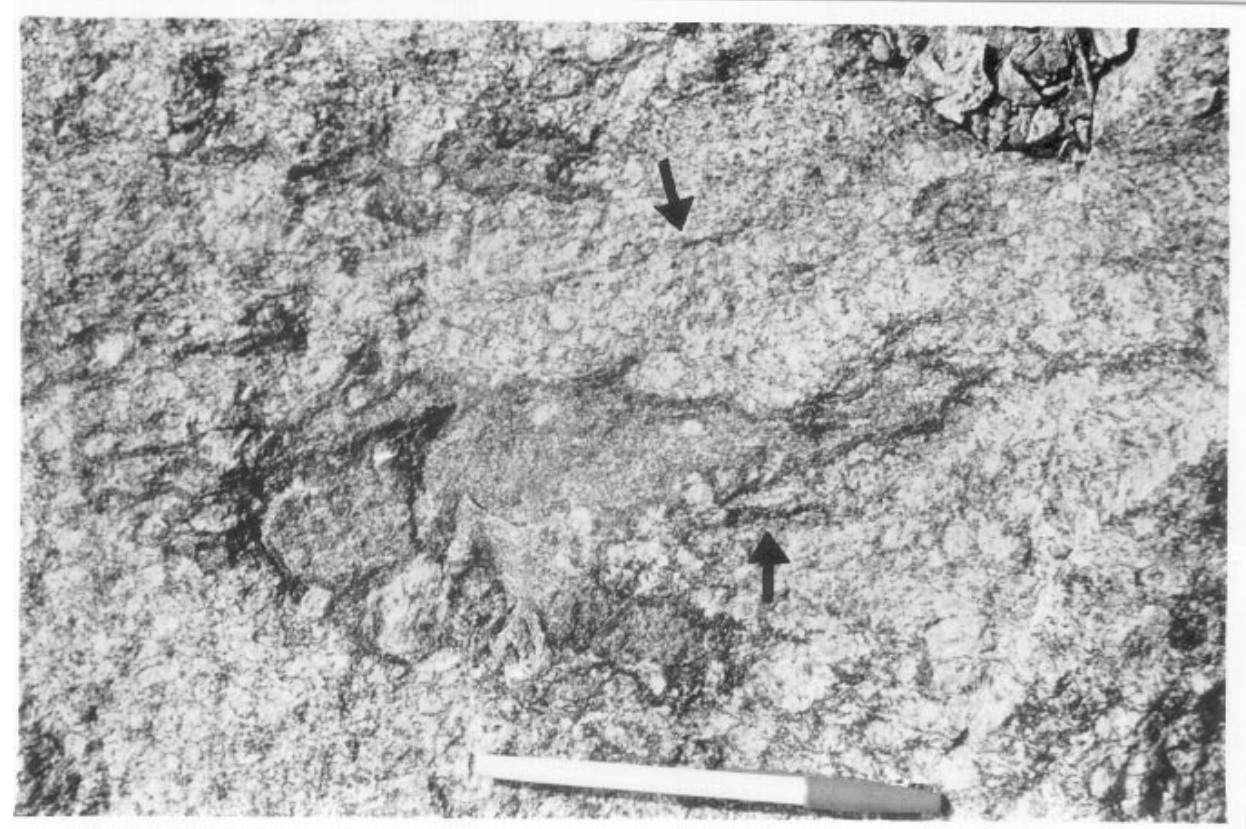

Figure 4. Folded charnockite patch in leptynitic host. Leptynitic foliation $\left(S_{2}\right)$ of the host (marked by arrow), roughly $\mathrm{E}-\mathrm{W}$, is axial planar to the fold.

The chemical composition of the patchy charnockites (table 4) can be described as granodioritic to tonalitic in a normative Ab-An-Or diagram (figure 7 ). They are metaluminous in character, as evidenced by their moderate $\mathrm{A} / \mathrm{CNK}$ values $(0.89,0.72)$. Moreover, the charnockite patches are rich in Niggli $\mathrm{fm}$ than the host leptynite (figure 8). In trace element composition, these charnockites are relatively depleted in $\mathrm{Rb}, \mathrm{Pb}$ contents and enriched in $\mathrm{Cu}, \mathrm{Ni}, \mathrm{Zn}$, Sr than the host leptynites (figure 9). Also, the patchy charnockites have a low $\mathrm{Rb} / \mathrm{Sr}$ ratio $(0.35,0.18)$, just opposite to the host leptynite. Additionally, the patchy charnockites are characterised by high $\mathrm{Ba}$ contents.

\subsection{Mineral chemistry}

The mineral chemical data are obtained by Electron Probe Micro Analysis. EPMA work was carried out at the University Science Instrumentation Center of the Roorkee University, 
Table 2. Modal mineralogy of different varieties of orthopyroxene-free granites.

\begin{tabular}{lcccccccc}
\hline Sample no. & Quartz & Alkali feldspar & Plagioclase & Garnet & Biotite & Hornblende & Opaque & Accessory \\
\hline JN138 & 33.6 & 50.8 & 12.8 & - & 0.8 & 0.2 & 1.6 & $0.2(\mathrm{Zr})$ \\
JN126B & 30 & 43.6 & 20.8 & - & 0.8 & 2 & 2.4 & $0.4(\mathrm{Zr})$ \\
2.J.65A & 31.6 & 58.4 & 8.8 & - & 0.4 & - & 0.8 & - \\
Jen 318A & 30.4 & 56.8 & 12 & - & - & - & 0.4 & $0.4(\mathrm{Zr})$ \\
Jen 303 & 26.8 & 56.4 & 16 & - & - & - & 0.8 & - \\
Jen 354A & 26.4 & 53.6 & 18.2 & - & 0.2 & - & 1.6 & - \\
JN58D/2 & 29.6 & 50.8 & 17.6 & - & 1.6 & - & 0.4 & - \\
JN135 & 31.2 & 49.4 & 16.8 & - & 2.4 & - & 0.2 & - \\
Jen 348A & 27.2 & 42 & 25.6 & 3.2 & 1.6 & - & 0.4 & - \\
JN 114D/2 & 33.6 & 52.4 & 12.4 & - & 0.8 & - & 0.8 & - \\
JN 50C & 25.6 & 51.6 & 16.8 & 3.2 & 1.2 & - & - & - \\
JN 48D & 34.8 & 45.2 & 20 & - & - & - & - & - \\
Jen 306 & 37.6 & 39.6 & 21.6 & 0.8 & 0.4 & - & - & - \\
JN 139 & 36.4 & 43.2 & 16.4 & - & 1.2 & 0.8 & 2 & - \\
JN 91 & 28 & 41.2 & 26.4 & - & 1.6 & - & 2.8 & 1.2 \\
2.J.60L & 32.4 & 53.2 & 12 & - & 0.8 & - & $0.4(\mathrm{Zr})$ \\
\hline
\end{tabular}

Zr: Zircon.

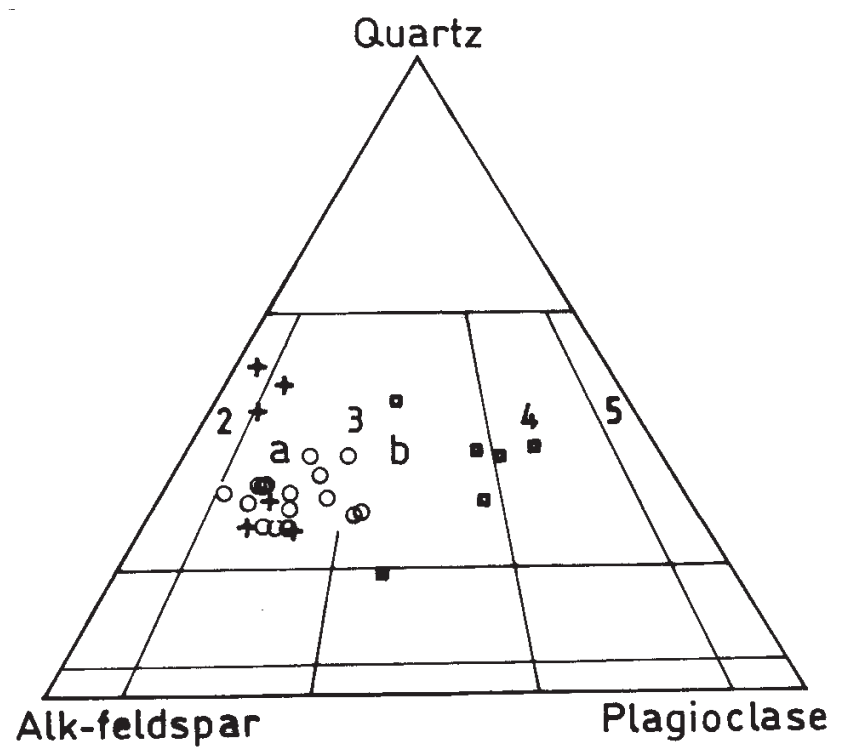

Figure 5. Modal Q-A-P plots, after Streckeisen (1976) of the orthopyroxene-free granites (circle), patchy charnockites (box) and host leptynites (plus).

using Jeol Jxa-8600M microprobe machine. 15 $\mathrm{kV}$ accelerating voltage, $2 \times 10^{-8}$ ampere sample current and $3 \mathrm{~mm}$ beam diameter were used. Mineral chemical data are presented in table 5 .

The plagioclases of the host granite are mostly andesine, Ab: $63-68 \%$, (table 5). However, a little variation in $\mathrm{X}_{\mathrm{An}} / \mathrm{X}_{\mathrm{Ab}}$ proportion is noticed in different microdomains (figure 10). Notably, all of them have very low molar $\mathrm{X}_{\mathrm{Or}}$ content $(2-$ $3 \%$ ). Similarly plagioclases of the patchy charnockites are also andesine, Ab: $60-65 \%$ (table 5). They are also poor in orthoclase (1-3\%). A little variation in $\mathrm{X}_{\mathrm{An}} / \mathrm{X}_{\mathrm{Ab}}$ proportions in different microdomains is also a notable feature (figure 10).
Garnet compositions in patchy charnockite are variable in different microdomains $\left(\mathrm{Alm}_{58} \mathrm{Py}_{21}\right.$ and $\mathrm{Alm}_{55} \mathrm{Py}_{25}$, see table 5). One important feature is that garnet shows subtle magnesium enrichment from core to rim, $\mathrm{Py}_{21}$ to $\mathrm{Py}_{23}$, indicating heating and/or decompression.

\section{P-T estimates}

P-T values are estimated from the coexisting garnet-clinopyroxene-plagioclase in the charnockite patches. The values are estimated by using the TWEEQU computer programme. Thermodynamic parameters of different minerals are taken from the internally consistent data set of Berman (1988 and updated database of 1992). Berman (1991) has shown that with the proper choice of solution models, this technique may estimate temperature and pressure with uncertainties less than $\pm 40^{\circ} \mathrm{C}$ and less than \pm 0.5 kbar respectively. For garnet, the solution model of Berman (1990) for quaternary garnet solid solutions is used. For plagioclase $\left(\mathrm{X}_{\mathrm{An}}>0.30\right)$, the alumina-avoidance model of Newton et al (1980) is not applicable and hence the model of Fuhrman and Lindsley (1988) is adopted. For pyroxenes an ideal solution model is adopted here, because this model fits well with the internally consistent database (Bhattacharya et al 1993b).

The pressure estimate is $7.75 \mathrm{kbar}$ at $660^{\circ} \mathrm{C}$ (table 5). Slightly higher temperature is also obtained from a separate microdomain $\left(700^{\circ} \mathrm{C}\right)$. This variation is consistent with the compositional variation of garnet and clinopyroxene. Notably, the high temperature domain has a higher $\mathrm{K}_{\mathrm{D}}^{\mathrm{Grt}-\mathrm{Cpx}}$ value and has relatively less magnesian pyroxene and more magnesian garnet than the low temper- 


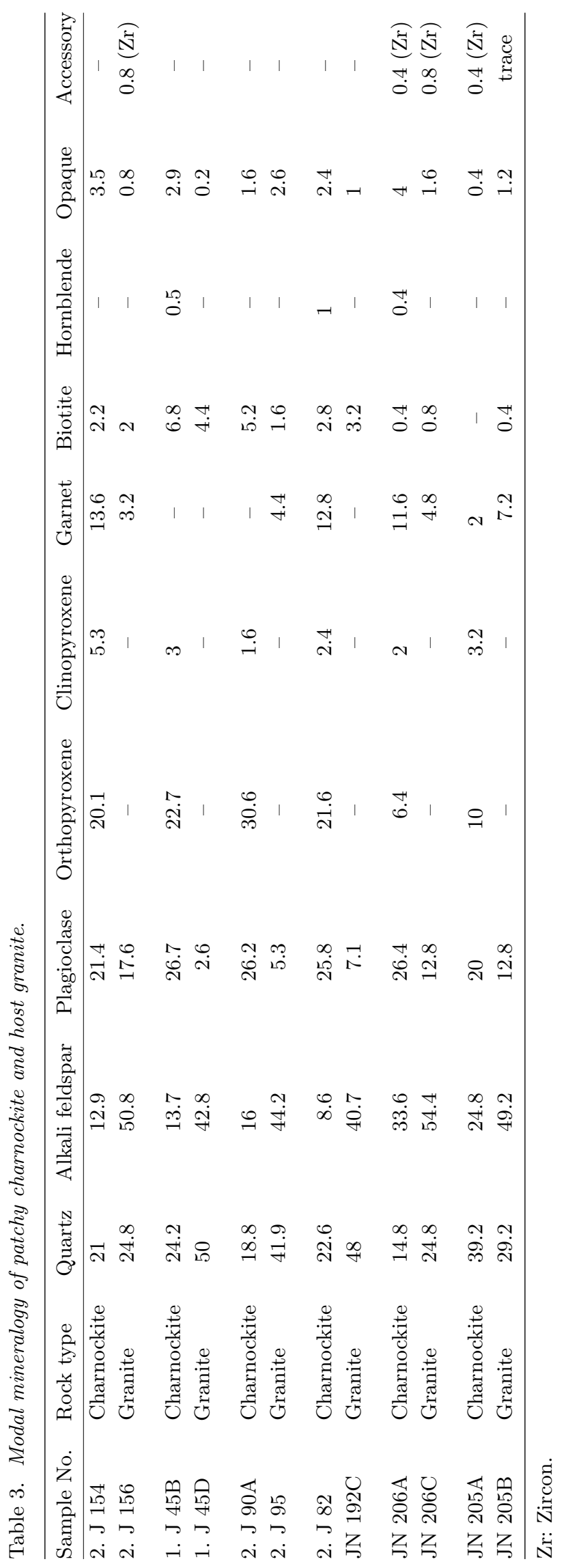




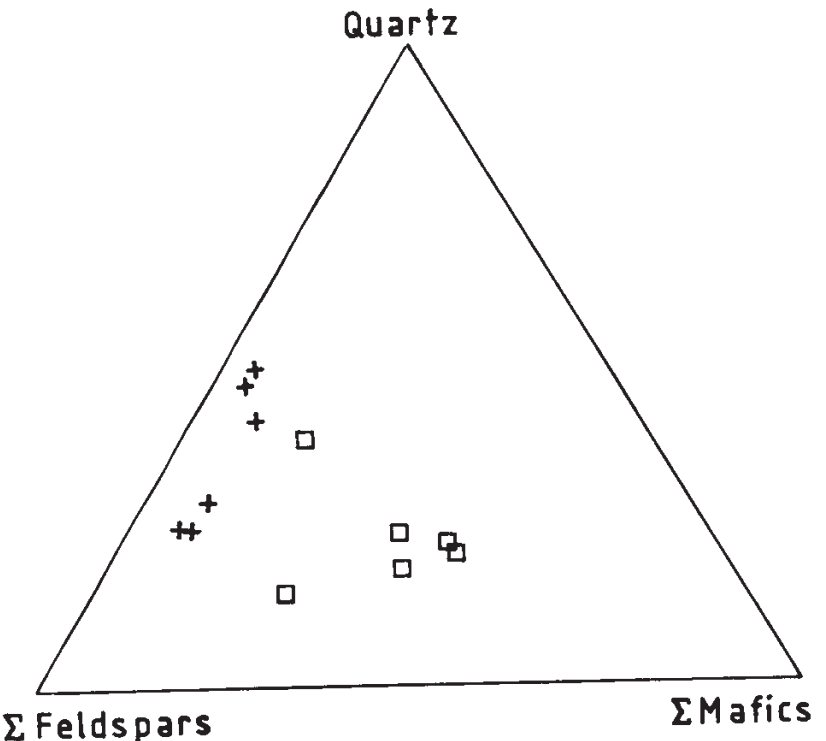

Figure 6. Modal quartz-feldspar-mafic proportions of patchy charnockites (box) and host leptynites (plus).

ature domain (table 5). These two domains probably represent two different frozen-in conditions, as proposed by Frost and Chacko (1989).

\section{Discussion}

Arrested charnockite formation is generally thought to be the product of subsolidus dehydration. The dehydration reaction vis-a-vis charnockite paragenesis can only form by decrease of water activity which could be either externally or internally controlled (cf. Hansen et al 1984; Srikantappa et al 1985). The external control of incipient charnockite formation assumes that the subsolidus dehydration of the gneiss assemblage was caused by decrease of $\mathrm{H}_{2} \mathrm{O}$ activity as a result of channelled influx of ' $\mathrm{CO}_{2}$-wave' from a deep mantle source (Janardhan et al 1982; Ravindrakumar and Chacko 1986; Santosh 1986, Hansen et al 1987a; Newton 1992b). On the other hand, Srikantappa et al (1985) envisaged that incipient charnockitization, i.e., dehydration could happen due to a decrease of fluid pressure with the onset of near-isothermal uplift following the peak stage of regional metamorphism.

It is noteworthy here that at P-T conditions $\left(\sim 6-7 \mathrm{kbar}, 700^{\circ}-800^{\circ} \mathrm{C}\right)$ and oxygen fugacity $\left(f_{\mathrm{O}_{2}}\right)$ below Q-F-M buffer, commonly recorded from the Eastern Ghats (Bhattacharya and Sen 1991; Sengupta et al 1991; Bhattacharya 1996; Dasgupta and Sengupta 1998 and this study, table 5), pervasive $\mathrm{CO}_{2}$ flooding sufficient to grow 10 volume\% orthopyroxene require 1.5 volume\% graphite to precipitate (Lamb and Valley
1984). The charnockite-leptynite association of the present area does not contain graphite. Hence, it is unlikely that $\mathrm{CO}_{2}$-flooding could be the causative mechanism of charnockite formation here.

On the other hand, the disposition of incipient charnockite along some structural weak zone, could be compatible with the internally controlled mechanism of charnockite formation, proposed by Srikantappa et al (1985) and modified by Raith and Srikantappa (1993). In the Eastern Ghats granulite belt, the incipient charnockites are thought to be produced along a near horizontal stretching lineation related to $F_{3}$ folding (Halden et al 1982; Dobmeier and Raith 2000). The charnockite patches described here are also disposed in a linear fashion (figure 2). However, they show the evidence of both $F_{3}$ folding and $F_{2}$ folding (figure 4). Also, they preserve the imprints of $S_{1}$ foliation. These field-structural features are not compatible with the hypothesis of arrested growth by an internally controlled mechanism.

On the other hand, arrested type charnockite formation, described from the Eastern Ghats granulite belt and elsewhere commonly indicate that the lithoboundary between the charnockite patch and host gneisses is diffused (Pichamuthu 1961; Janardhan et al 1979, 1982; Halden et al 1982; Ravindrakumar et al 1985; Srikantappa et al 1985; Ravindrakumar and Chacko 1986; Hansen et al 1987b; Newton 1992b; Raith and Srikantappa 1993; Dobmeier and Raith 2000). Whatever may be the mechanism for metamorphic transformation, this field relation is said to be critical. In contrast, the lithoboundary between charnockite patches and host gneiss is very sharp here (figures 2, 3 and 4), and this argues against the arrested growth hypothesis.

In modal mineralogy and bulk chemistry the leptynites are granitic in composition with high normative orthoclase, while the patchy charnockites are mostly granodioritic in composition with much less normative orthoclase (figure 7). Moreover, the patchy charnockites are metaluminous while the host leptynites are peraluminous in character (table 4). Hence, it can be suggested from these observations that patchy charnockites and host leptynites are mineralogically and chemically distinct entities.

The patchy charnockites have comparatively lower $\mathrm{Rb} / \mathrm{Sr}$ ratios than the host leptynites. It should be noted here that leptynite from other parts of the Eastern Ghats has been described as product of biotite-dehydration melting (Sen and Bhattacharya 1997), and they are characterised by high $\mathrm{Rb} / \mathrm{Sr}$ ratio. On the other hand, the 
Table 4. Bulk chemistry of patchy charnockite and host leptynite.

\begin{tabular}{|c|c|c|c|c|}
\hline \multirow{2}{*}{$\frac{\text { Rock type }}{\text { Sample no }}$} & \multicolumn{2}{|c|}{ Charnockite } & \multicolumn{2}{|c|}{ Leptynite } \\
\hline & JN 205A & JN 206A & JN 205B & $\mathrm{JN} 206 \mathrm{C}$ \\
\hline $\mathrm{SiO}_{2}$ & 60.58 & 51.65 & 70.55 & 73.66 \\
\hline $\mathrm{TiO}_{2}$ & 2.42 & 1.28 & 0.57 & 0.4 \\
\hline $\mathrm{Al}_{2} \mathrm{O}_{3}$ & 14.04 & 16.83 & 14.85 & 14.14 \\
\hline $\mathrm{Fe}_{2} \mathrm{O}_{3}$ & 11.3 & 9.1 & 4.28 & 2.86 \\
\hline $\mathrm{MnO}$ & 0.23 & 0.13 & 0.06 & 0.04 \\
\hline $\mathrm{MgO}$ & 1.53 & 7.06 & 0.39 & 0.26 \\
\hline $\mathrm{CaO}$ & 4.6 & 8.71 & 2 & 1.65 \\
\hline $\mathrm{Na}_{2} \mathrm{O}$ & 2.54 & 3.15 & 2.36 & 2.35 \\
\hline $\mathrm{K}_{2} \mathrm{O}$ & 2.93 & 2.11 & 5.52 & 5.76 \\
\hline $\mathrm{P}_{2} \mathrm{O}_{5}$ & 0.71 & 0.5 & 0.22 & 0.15 \\
\hline Total & 100.88 & 100.52 & 100.00 & 101.26 \\
\hline LOI & 1.78 & 0.78 & 0.4 & 0.47 \\
\hline $\mathrm{A} / \mathrm{CNK}$ & 0.89 & 0.72 & 1.04 & 1.08 \\
\hline \multicolumn{5}{|c|}{ Normative values } \\
\hline Q & 18.04 & 0 & 28.64 & 32.53 \\
\hline $\mathrm{C}$ & 0 & 0 & 0.95 & 1.28 \\
\hline Or & 17.35 & 12.5 & 32.7 & 34.11 \\
\hline $\mathrm{Ab}$ & 21.49 & 26.65 & 19.97 & 19.88 \\
\hline An & 18.37 & 25.62 & 8.9 & 7.6 \\
\hline $\mathrm{Ol}$ & 0 & 13.55 & 0 & 0 \\
\hline \multicolumn{5}{|c|}{ Niggli values } \\
\hline $\mathrm{c}$ & 17.28 & 22.69 & 10.67 & 9.49 \\
\hline alk & 15.19 & 10.69 & 28.92 & 31.96 \\
\hline $\mathrm{fm}$ & 38.5 & 42.49 & 19.17 & 13.79 \\
\hline \multicolumn{5}{|c|}{ Trace elements } \\
\hline $\mathrm{Cr}$ & 25 & 187 & 28 & 43 \\
\hline $\mathrm{Ni}$ & 24 & 37 & 8 & 13 \\
\hline $\mathrm{Cu}$ & 10 & 23 & 5 & 3 \\
\hline $\mathrm{Pb}$ & 21 & 18 & 33 & 48 \\
\hline $\mathrm{Zn}$ & 129 & 91 & 58 & 36 \\
\hline K & 24323 & 17516 & 45823 & 47815 \\
\hline $\mathrm{Rb}$ & 91 & 77 & 202 & 178 \\
\hline $\mathrm{Ba}$ & 2138 & 1528 & 1393 & 1287 \\
\hline $\mathrm{Sr}$ & 260 & 436 & 139 & 152 \\
\hline $\mathrm{Ga}$ & 24 & 16 & 20 & 17 \\
\hline $\mathrm{Nb}$ & 63 & 15 & 23 & 12 \\
\hline $\mathrm{Zr}$ & 483 & 182 & 298 & 267 \\
\hline $\mathrm{Ti}$ & 14507 & 7673 & 3417 & 2398 \\
\hline Y & 70 & 20 & 23 & 25 \\
\hline Th & 21 & 3 & 11 & 102 \\
\hline $\mathrm{Rb} / \mathrm{Sr}$ & 0.35 & 0.18 & 1.45 & 1.17 \\
\hline
\end{tabular}

massif-type charnockites in the study area has been described as a product of hornblende-dehydration melting (Kar et al 2000), and they are characterised by low $\mathrm{Rb} / \mathrm{Sr}$ ratio. Hence, in the study area, the patchy charnockites could be the product of hornblende-dehydration melting while the host leptynites could be the product of biotite-dehydration melting. However, the relatively higher Ba contents in the patchy charnockites than the host leptynites is the most unusual feature. Large amounts of fractional crystallization could produce this feature, so that early separated K-feldspar might have incorporated $\mathrm{Rb}$, while $\mathrm{Ba}$ entered into the late crystallizing K-feldspar.

The subtle magnesium enrichment in the rim of a garnet from patchy charnockite can be inter- preted as a result of heating; the heat being released from crystallisation of the host leptynite (granite). More magnesian rim could also be related to decompression accompanying emplacement of the leptynite (granite). In this context it is important to note that Sen et al (1995) recorded lower pressure $(\sim 6 \mathrm{kbar})$ from patchy charnockites as compared to larger bodies of charnockites $(\sim 8 \mathrm{kbar})$ from the Chilka Lake area.

\section{Conclusion and implication}

The charnockite patches preserve the imprints of early deformational structures, which are char- 


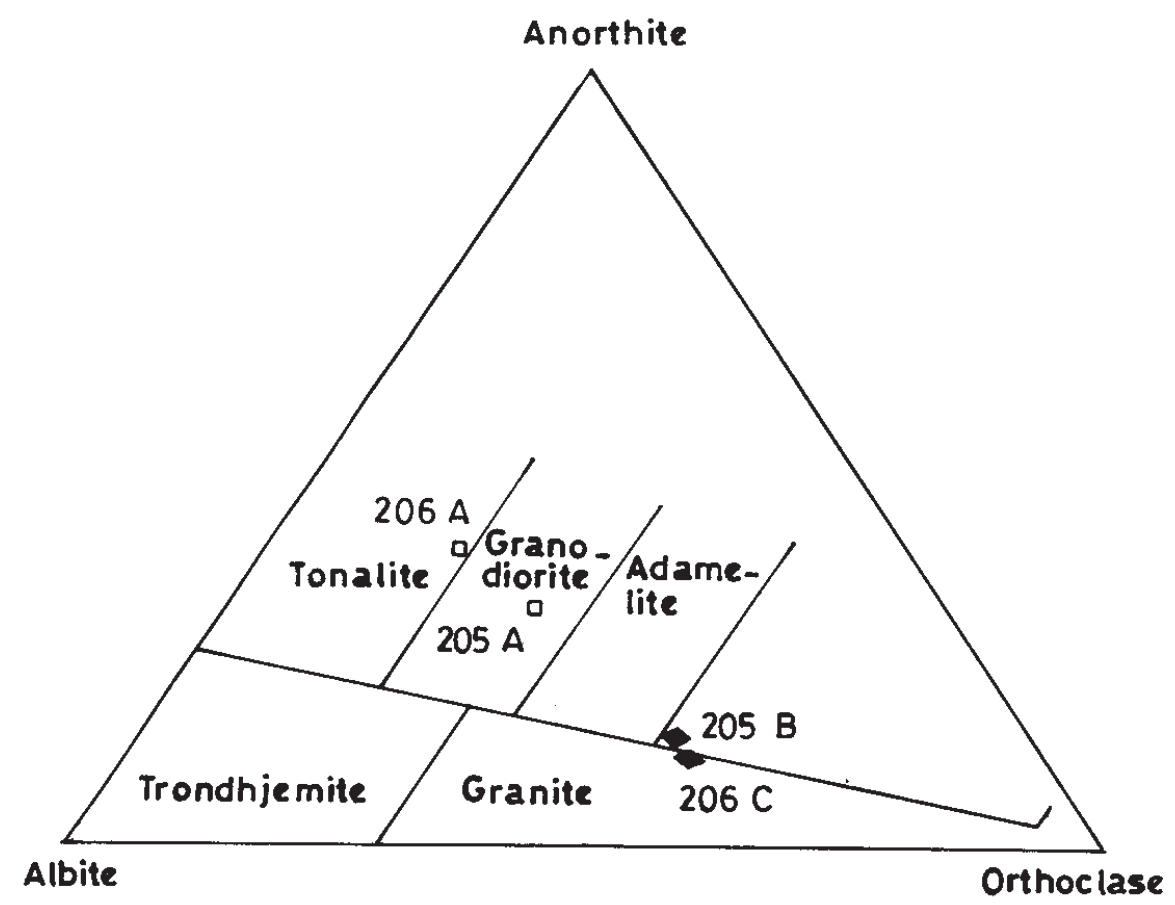

Figure 7. Normative Ab-An-Or proportions of patchy charnockites (box) and adjacent host leptynite (solid rhomb), after Le Maitre (1989); sample numbers are given.

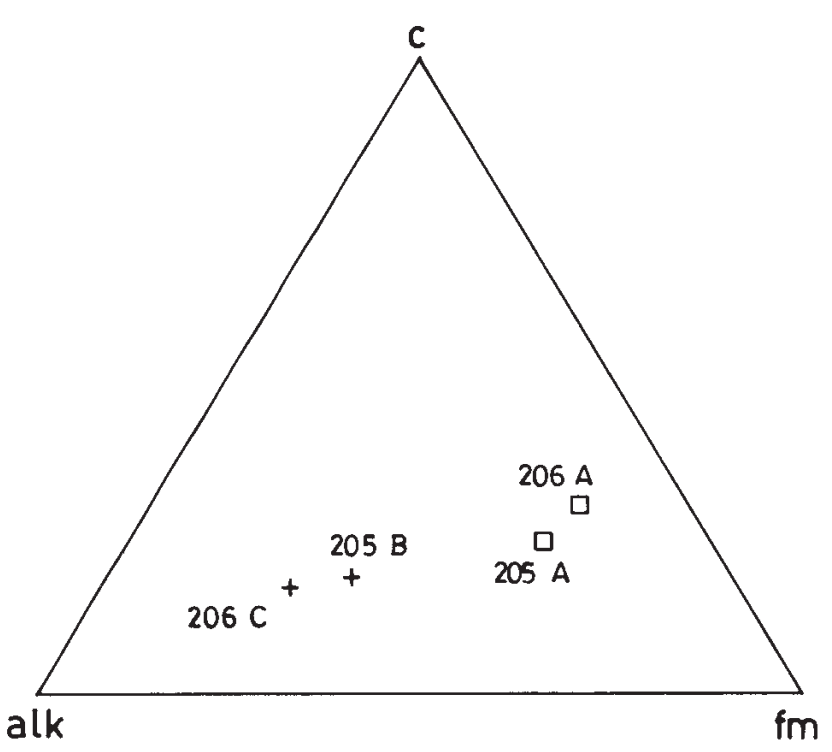

Figure 8. Niggli $c$-fm-alk proportions of patchy charnockites (box) and adjacent host leptynite (plus); sample numbers are given.

acteristically absent in the leptynitic host. Also, the charnockite patches are mineralogically and chemically distinct from the host. The distinctive mineralogy and chemistry, and especially the $\mathrm{Rb} / \mathrm{Sr}$ ratio, clearly suggests different source rocks for patchy charnockites and leptynites; hornblende and biotite dominated respectively. Hence, it can be concluded that (1) the charnockitic patches are relict and (2) the patchy charnockite and host leptynite are genetically unrelated.

The leptynite is commonly thought to be the product of crustal melting of a pelitic source (Sen 1987; Karmakar and Fukuoka 1992; Sen and Bhattacharya 1997). In the Eastern Ghats, this melting event is correlated to regional $F_{2}$ deformation (Sen and Bhattacharya 1997). Notably, the leptynite here also contain only $S_{2}$ fabric. On the other hand, the charnockitic patches frequently record $F_{2}$ folding and preserve the imprint of $S_{1}$ foliation on mesoscopic and microscopic scale. These lead me to suggest that the charnockitic patches originated during or prior to regional $F_{1}$ folding event in the Eastern Ghats. Later on, they are caught up within the host leptynite (granitic melt) during $F_{2}$ folding.

Finally, the massif-type charnockite body in the adjoining area, which has been interpreted as the product of hornblende-dehydration melting, synkinematic with $F_{1}$ deformation (Kar et al 2000) and relict charnockite patches with both the structural imprints of $F_{1}$ and chemical signature of hornblende-dehydration melting, are most likely cogenetic. An important idea emerges from the present study: charnockitic rocks of different modes of occurrence, if found in adjoining areas, both should be investigated before proposing a petrogenetic model or hypothesis for any one of them. 


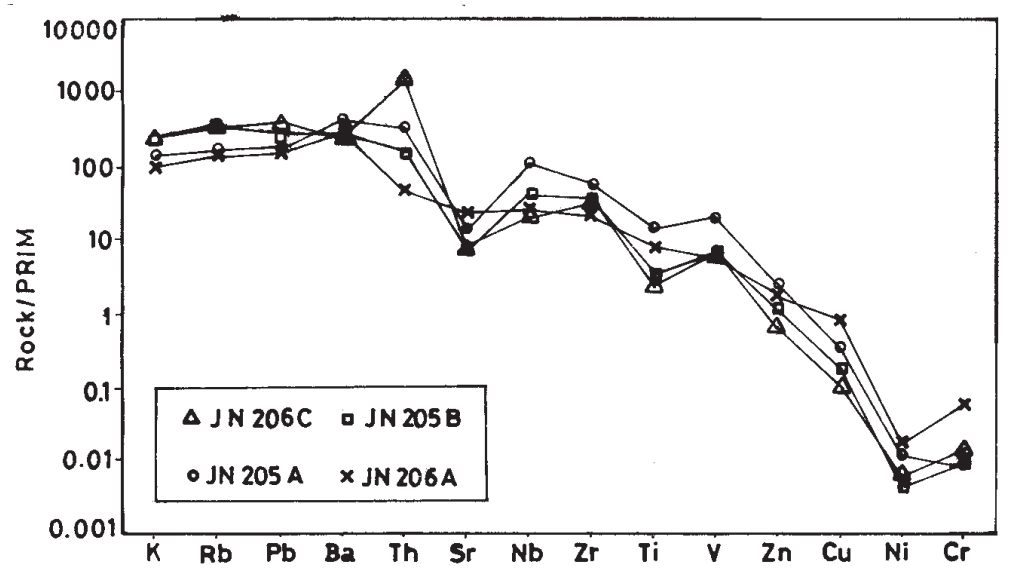

Figure 9. Primitive mantle (PRIM of Taylor and McLennan 1985) normalised multi-element plots of patchy charnockites and host leptynites; sample numbers are given in inset box.

Table 5. Representative mineral chemistry from patchy charnockite and host orthopyroxene-free granite.

\begin{tabular}{|c|c|c|c|c|c|c|c|c|c|c|c|}
\hline \multirow{3}{*}{$\begin{array}{l}\text { Sample no. } \\
\text { Microdomain } \\
\text { Mineral phases }\end{array}$} & \multicolumn{8}{|c|}{ JN 205A (charnockite patch) } & \multicolumn{3}{|c|}{ Jen 303 (leucogranite) } \\
\hline & \multicolumn{3}{|c|}{1} & \multicolumn{3}{|c|}{2} & \multicolumn{2}{|c|}{3} & 1 & 2 & 3 \\
\hline & \multicolumn{2}{|c|}{ Garnet } & \multirow{2}{*}{$\begin{array}{l}\text { Plag } \\
\text { Core }\end{array}$} & \multirow{2}{*}{$\begin{array}{c}\text { Garnet } \\
\text { Core }\end{array}$} & \multirow{2}{*}{$\begin{array}{l}\text { Cpx } \\
\text { Core }\end{array}$} & \multirow{2}{*}{$\begin{array}{l}\text { Plag } \\
\text { Core }\end{array}$} & \multirow{2}{*}{$\begin{array}{c}\text { Garnet } \\
\text { Core }\end{array}$} & \multirow{2}{*}{$\begin{array}{c}\text { Cpx } \\
\text { Core }\end{array}$} & \multicolumn{3}{|c|}{ Plag } \\
\hline Locations & Core & Rim & & & & & & & Core & Core & Core \\
\hline Reference no. & $5 / 1$ & $5 / 2$ & $5 / 3$ & $5 / 4$ & $5 / 5$ & $5 / 6$ & $5 / 7$ & $5 / 8$ & $5 / 9$ & $5 / 10$ & $5 / 11$ \\
\hline $\mathrm{SiO}_{2}$ & 38.46 & 40.34 & 59.74 & 39.32 & 53.37 & 59.81 & 40.53 & 52.92 & 61.19 & 61.21 & 60.84 \\
\hline $\mathrm{Al}_{2} \mathrm{O}_{3}$ & 21.82 & 22.37 & 25.05 & 22.02 & 1.93 & 25.53 & 22.14 & 1.79 & 24.94 & 25.11 & 25.25 \\
\hline $\mathrm{FeO}$ & 26.64 & 25.15 & 0 & 26.69 & 8.56 & 0 & 24.91 & 9.88 & 0 & 0 & 0 \\
\hline $\mathrm{MnO}$ & 1.03 & 0.82 & 0 & 0.75 & 0.05 & 0 & 0.68 & 0.07 & 0 & 0 & 0 \\
\hline $\mathrm{MgO}$ & 5.65 & 5.96 & 0 & 5.63 & 15.33 & 0 & 6.51 & 15.09 & 0 & 0 & 0 \\
\hline $\mathrm{CaO}$ & 6.67 & 6.72 & 6.91 & 6.73 & 21.59 & 6.82 & 6.65 & 21.31 & 6.47 & 6.68 & 6.31 \\
\hline $\mathrm{Na}_{2} \mathrm{O}$ & 0 & 0 & 6.2 & 0 & 0.57 & 7.22 & 0 & 0.59 & 6.57 & 6.65 & 7.85 \\
\hline $\mathrm{K}_{2} \mathrm{O}$ & 0 & 0 & 0.38 & 0 & 0.02 & 0.18 & 0 & 0.06 & 0.39 & 0.37 & 0.36 \\
\hline $\mathrm{TiO}_{2}$ & 0.07 & 0.03 & 0 & 0.03 & 0.26 & 0 & 0.05 & 0.27 & 0 & 0 & 0 \\
\hline Summation & 100.72 & 101.39 & 98.28 & 101.17 & 101.68 & 99.56 & 101.47 & 101.98 & 99.56 & 100.02 & 100.61 \\
\hline Oxygen & 12 & 12 & 8 & 12 & 6 & 8 & 12 & 6 & 8 & 8 & 8 \\
\hline$\overline{\mathrm{Si}}$ & 2.99 & 3.09 & 2.74 & 3.03 & 1.94 & 2.68 & 3.08 & 1.92 & 2.76 & 2.75 & 2.69 \\
\hline $\mathrm{Al}$ & 1.99 & 2.02 & 1.35 & 1.99 & 0.08 & 1.35 & 1.99 & 0.08 & 1.33 & 1.33 & 1.32 \\
\hline $\mathrm{Fe}_{2}$ & 1.74 & 1.64 & - & 1.73 & 0.26 & - & 1.61 & 0.29 & - & - & - \\
\hline $\mathrm{Fe}_{3}$ & - & - & - & - & - & - & - & 0.01 & - & - & - \\
\hline $\mathrm{Mn}$ & 0.06 & 0.04 & - & 0.04 & - & - & 0.04 & - & - & - & - \\
\hline $\mathrm{Mg}$ & 0.65 & 0.68 & - & 0.65 & 0.83 & - & 0.74 & 0.82 & - & - & - \\
\hline $\mathrm{Ca}$ & 0.55 & 0.55 & 0.34 & 0.57 & 0.84 & 0.33 & 0.54 & 0.83 & 0.31 & 0.32 & 0.29 \\
\hline $\mathrm{Na}$ & - & - & 0.55 & - & 0.04 & 0.63 & - & 0.04 & 0.58 & 0.58 & 0.67 \\
\hline $\mathrm{K}$ & - & - & 0.02 & - & - & 0.01 & - & - & 0.02 & 0.02 & 0.02 \\
\hline $\mathrm{Ti}$ & - & - & - & - & - & - & - & 0.01 & - & - & - \\
\hline Sum cation & 7.98 & 8.02 & 5 & 8.01 & 3.99 & 5 & 8 & 4 & 5 & 5 & 4.99 \\
\hline $\mathrm{X}$ alm & 0.58 & 0.56 & NA & 0.58 & NA & NA & 0.55 & NA & NA & NA & NA \\
\hline X py & 0.21 & 0.23 & NA & 0.22 & NA & NA & 0.25 & NA & NA & NA & NA \\
\hline $\mathrm{X}$ gr & 0.18 & 0.19 & NA & 0.19 & NA & NA & 0.19 & NA & NA & NA & NA \\
\hline X sp & 0.03 & 0.02 & NA & 0.01 & NA & NA & 0.01 & NA & NA & NA & NA \\
\hline $\mathrm{X}$ fsl & NA & NA & NA & NA & 0.13 & NA & NA & 0.15 & NA & NA & NA \\
\hline X en & NA & NA & NA & NA & 0.43 & NA & NA & 0.42 & NA & NA & NA \\
\hline $\mathrm{X}$ wo & NA & NA & NA & NA & 0.44 & NA & NA & 0.43 & NA & NA & NA \\
\hline $\mathrm{X}$ an & NA & NA & 0.37 & NA & NA & 0.34 & NA & NA & 0.34 & 0.35 & 0.3 \\
\hline $\mathrm{X} a b$ & NA & NA & 0.6 & NA & NA & 0.65 & NA & NA & 0.63 & 0.63 & 0.68 \\
\hline $\mathrm{X}$ or & NA & NA & 0.03 & NA & NA & 0.01 & NA & NA & 0.03 & 0.02 & 0.02 \\
\hline $\mathrm{K}_{\mathrm{D}}$ grt-cpx & & NA & & & 0.357 & & 0.4 & & & NA & \\
\hline $\mathrm{T}^{\circ} \mathrm{C}$ & & NA & & & $660^{\circ} \mathrm{C}$ & & 700 & & & NA & \\
\hline P (kbar) & & NA & & & $.75 \mathrm{kbar}$ & & & & & NA & \\
\hline
\end{tabular}

Note: Plag - Plagioclase; Cpx - Clinopyroxene. 


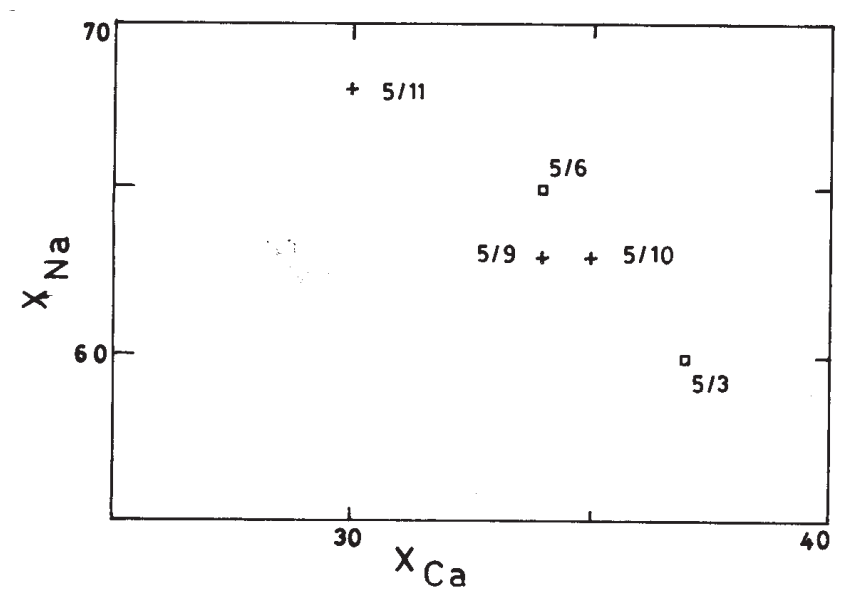

Figure 10. $\mathrm{X}_{\mathrm{Ca}}$ vs. $\mathrm{X}_{\mathrm{Na}}$ plots of plagioclase. Box: patchy charnockite. Plus: leucogranite host. Reference numbers follow table 5 .

\section{Acknowledgements}

I thankfully acknowledge the generous help by Dr. S Bhattacharya, Geological Studies Unit, Indian Statistical Institute for successful completion of the work. I owe my regards to Prof. A T Rao and Prof. Karl E Seifert for critical reviewing and constructive comments on an earlier version of the manuscript. The infrastructural facilities provided by the Indian Statistical Institute are also thankfully acknowledged.

\section{References}

Aftalion M, Bowes D R, Dash B and Dempster T J 1988 Late Proterozoic charnockites in Orissa, India: $\mathrm{A} \mathrm{U}-\mathrm{Pb}$ and $\mathrm{Rb}-\mathrm{Sr}$ isotopic study; J.Geol. 96 663-676

Berman R G 1988 Internally consistent thermodynamic data for minerals in the system $\mathrm{Na}_{2} \mathrm{O}-\mathrm{K}_{2} \mathrm{O}-\mathrm{CaO}-\mathrm{MgO}-\mathrm{FeO}-$ $\mathrm{Fe}_{2} \mathrm{O}_{3}-\mathrm{Al}_{2} \mathrm{O}_{3}-\mathrm{SiO}_{2}-\mathrm{TiO}_{2}-\mathrm{H}_{2} \mathrm{O}-\mathrm{CO}_{2} ;$ J. Petrol. $29445-$ 522

Berman R G 1990 Mixing properties of Ca-Mg-Fe-Mn garnets; Am. Mineral. 75 328-344

Berman R G 1991 Thermobarometry using multiequilibrium calculations: A new technique, with petrological applications; Can. Mineral. 29 833-855

Bhattacharya A and Sen S K 1991 Pressure, Temperature and Fluid regime in selected granulites tracts of the Eastern Ghats of India; (Abstract) In: Proceedings seminar on "composition and evolution of high-grade gneiss terrains", IGCP Project 304, Lower crustal process, Kandy, Sri Lanka.

Bhattacharya S 1996 Eastern Ghats granulite terrain of India: an overview; J. Southeast Asian Earth Sci. 14 165174

Bhattacharya S, Sarkar S S and Acharyya A 1993b Thermodynamic calibrations based on a single internally consistent data set; Indian J. Geol. 65 267-281

Bhattacharya S, Sen S K and Acharyya A 1993a Structural evidence supporting a remnant origin of patchy charnockites in the Chilka Lake area, India; Geol. Mag. $130363-$ 368
Bhattacharya S, Sen S K and Acharyya A 1994 The structural setting of the Chilka Lake granulite-migmatiteanorthosite suite with emphasis on the time relation of charnockites; Pre. Res. 66 393-409

Dasgupta S and Sengupta P 1998 Reworking of an isobarically cooled continental crust. Evidence of decompressive P-T trajectory from the Eastern Ghats belt, India; Indian J. Geol. 70 133-144

De Waard D 1969 The occurrence of charnockite in the Adirondacks: a note on the origin and definition of charnockite; Am. J. Sci. 267 983-987

Dobmeier C and Raith M 2000 On the origin of 'arrested' charnockitization in the Chilka Lake area, Eastern Ghats Belt, India: a reappraisal; Geol. Mag. 137 27-37

Frost B R and Chacko T 1989 The granulite uncertainty principle: limitations on the thermobarometry in granulites; J. Geol. 97 435-450

Fuhrman M L and Lindsley D H 1988 Ternary-feldspar modelling and thermometry; Am. Mineral. 73 201-216

Halden N M, Bowes D R and Dash B 1982 Structural evolution of migmatites in a granulite facies terrane: Precambrian crystalline complex of Angul, Orissa, India; Trans. Royal Soc. Edin., Earth Sci. 73 109-118

Hansen E C, Janardhan A S, Newton R C, Prame W K B N and Rabindrakumar G R 1987b Arrested charnockite formation in south India and Sri Lanka; Contrib. Mineral. Petrol. 96 225-244

Hansen E C, Janardhan A S, Newton R C, Prame W K B N and Ravindra Kumar G R 1987a Arrested charnockite formation at Kabbaldurga, South India; Nature 278 511514

Hansen E C, Newton R C and Janardhan A S 1984 Fluid inclusion in rocks from the amphibolite-facies gneiss to charnockite progression in southern Karnataka, India: Direct evidence concerning the fluids of granulite metamorphism; J. Metamorphic Geol. 2 249-264

Harley S L and Santosh M 1995 Wollastonite at Nuliyam, Kerala, South India: a reassessment of $\mathrm{CO}_{2}$ infiltration and charnockite formation at a classic locality; Contrib. Mineral. Petrol. 120 83-94

Holland T H 1893 The petrology of Job Charnocks' tombstone; J. Asiatic Soc. Bengal 62 162-164

Holland T H 1900 The charnockite series, a group of Archaean hypersthene rocks in Peninsular India; Geol. Survey Indian Memoir 2 192-249

Howie R A 1955 The geochemistry of the charnockite series of Madras, India; Trans. Royal Soc. Edin., Earth Sci., 62 $725-768$

Janardhan A S and Francis Anto K 1996 Transition zone charnockites-Harbingers of granulite metamorphism? Examples from South India; Gond. Res. Gr. Memoir3: The Archaean and Proterozoic terrain in South India within East Gondwana. (eds) M Santosh and M Yoshida, $145-155$

Janardhan A S, Jayananda $M$ and Shankara M A 1994 Formation and tectonic evolution of granulites from the Biligirirangan and Nilgiri Hills, South India: Geochemical and Isotopic constraints; J. Geol. Soc. Indian 44 27-40

Janardhan A S, Newton R C and Hansen E C 1982 The transformation of amphibolite facies gneiss to charnockite in southern Karnataka and northern Tamil Nadu, India; Contrib. Mineral. Petrol. 79 130-149

Janardhan A S, Newton R C and Smith J V 1979 Ancient crustal metamorphism at low $\mathrm{P}_{\mathrm{H}_{2} \mathrm{O}}$ : charnockite formation at Kabbaldurga, South India; Nature 278 511-514

Kar R 1995 Structural setting and post-granulite modification in an area in the northeastern sector of Eastern Ghats Indian J. Geol. 67 273-281 
Kar R, Bhattacharya S and Sheraton J W 2000 Hornblendedehydration melting in mafic rocks and the link between massif-type charnockite and associated granulites, Eastern Ghats Granulite belt, India; (revised manuscript submitted to J. Petrol.)

Karmakar S and Fukuoka M 1992 Genesis of leptynites: evidence from Araku valley, Eastern Ghats, India; Indian Mineral. 46 247-258

Kilpatrick J A and Ellis D J 1992 C-type magma: igneous charnockites and their extrusive equivalents; Trans. Royal Soc. Edin., Earth Sci. 83 155-164

Lamb W and Valley J W 1984 Metamorphism of reduced granulites in low- $\mathrm{CO}_{2}$ vapour-free environment; Nature $31256-58$

Le Maitre R W 1989 A classification of igneous rocks and glossary of terms; (Oxford: Blackwell), 193 pp.

Merh S S 1962 Structural aspects of the charnockitic rocks of Palavered, Madras State; J. M U University, Baroda 11 123-128

Naha K, Srinivasan R and Jayaram S 1993 Structural relations of the charnockites of the Archaean Dharwar Craton, Southern India; J. Metamorphic Geol. 11 889-895

Naha K 1988 Structural relations of charnockites of South India; J. Geol. Soc. India 31 114-115

Newton R C 1992a An overview of charnockite; Pre. Res. 55 399-405

Newton R C 1992b Charnockite alteration: evidence for $\mathrm{CO}_{2}$ infiltration in granulite facies metamorphism; J. Metamorphic Geol. 10 383-400

Newton R C, Charlu T V and Kleppa O J 1980 Thermochemistry of high structural state plagioclases; Geochem. Cosmochem. Acta 44 933-941

Paul D K, RayBarman T, McNaughton N J, Fletcher J R, Potts $\mathrm{P}$ J, Ramakrishnan $\mathrm{M}$ and Augustine $\mathrm{P} F$ 1990 Archaean-Proterozoic evolution of Indian charnockites: Isotopic and geochemical evidence from granulites of Eastern Ghats belt; J. Geol. 98 253-263

Pichamuthu C S 1960 Charnockite in the making; Nature $188135-136$

Pichamuthu C S 1961 Transformation of Peninsular gneiss into charnockite in Mysore state, India; J. Geol. Soc. India 2 46-49

Pichamuthu C S 1969 Nomenclature of charnockites; Indian Mineral. 10 23-35

Raith M and Srikantappa C 1993 Arrested charnockite formation at Kottavattam, southern India; J. Metamorphic Geol. 11 815-832

Raith M, Srikantappa C, Ashamanjari K G and Spiering B 1990 The granulite terrain of Nilgiris (south India): characterization of high grade metamorphism. In : 'Granulites and Crustal Evolution'; NATO ASI Series C (eds) D. Vielzeuf and Vidal Ph 311 339-365

Rao A T, Saradhi P and Srinivas S 1995 Chlorine rich coexisting hornblende and biotite from charnockites of Eleswaram in the Eastern Ghats granulite belt; In: Gond. Res. Gr. Mis. Publ. No. 2, (eds) A T Rao, S R Divi and M Yoshida. Andhra University, Visakhapatnam, India, 47.
Ravindra-Kumar G R and Chacko T 1986 Mechanism of charnockite formation and breakdown in charnockitekhondalite terrain of southern Kerala: implications for the origin of the southern Indian granulite terrain; J.Geol. Soc. India 28 277-288

Ravindra-Kumar G R, Srikantappa C and Hansen E C 1985 Charnockite formation at Ponmudi in southern India; Nature 313 207-209

Ridley J 1992 On the origin and tectonic significance of the charnockite suite of the Archaean Limpopo Mobile Belt, Northern Marginal Zone, Zimbabwe; Pre. Res. 55 407427

Santosh M 1986 Carbonic metamorphism of charnockites in the southwestern Indian Shield: a fluid inclusion study; Lithos 19 1-10

Sen S K 1987 Origin of leptynites, an orthopyroxene-free granite gneiss in two granulite terranes of India. Recent researches in Geology. In: Geol. evol Peninsular Ind., Petrol. and Struc. aspect, (ed.). A K Saha Hindusthan Pub 13 117-124

Sen S K and Bhattacharya S 1993 Patchy charnockites from south Kerala: relicts or nascent growth; Indian Mineral. 47 103-112

Sen S K and Bhattacharya S 1997 Dehydration melting of micas in the Chilka Lake Khondalites: The link between the metapelites and granitoids; Proc. Indian Acad. Sci. (Earth Planet. Sci.) $\mathbf{1 0 6}$ 277-297

Sen S K, Bhattacharya S and Acharyya A 1995 A multistage pressure-temperature record in the Chilka Lake granulites: the epitome of the metamorphic evolution of Eastern Ghats, India; J. Metamorphic Geol. 13 287-298

Sengupta P, Karmakar S, Dasgupta S and Fukuoka M 1991 Petrology of spinel granulites from Araku, Eastern Ghats, India, and a petrogenetic grid from sapphirine free rocks in the system FMAS; J. Metamorphic Geol. 9 451-459

Shaw R K 1996 Structural features of granulites from Rayagada, Eastern Ghats, India: some preliminary observations; J. Mineral. Petrol. Eco. Geol. 91 443-454

Srikantappa C, Raith M and Speiring B 1985 Progressive charnockitisation of a leptynite-khondalite suite in southern Kerala, India - evidence for formation of charnockites through decrease of fluid pressure; J. Geol. Soc. India 26 849-872

Srikantappa C, Raith M and Touret J L R 1992 Synmetamorphic high-density carbonic fluids in the lower crust: Evidence from the Nilgiri granulite, South India; J. Petrol. 33 733-760

Stahle H J, Raith M, Hoernes S and Delfs A 1987 Element mobility during incipient granulite formation at Kabbaldurga, southern India; J. Petrol. 28 803-834

Streckeisen A L 1976 To each plutonic rock its proper name; Earth Sci. Rev. 12 1-33

Subba Rao M V, Charan S N and Divakar Rao V 1995 Diversity of the chemical signatures of the charnockite suite of rocks in the Eastern Ghats mobile belt: implications for the nature and origin of their protolith; In: Gond. Res. Gr. Mis. Pub. No. 2, (eds) A T Rao, S R Divi and M Yoshida. Andhra University, Visakhapatnam, India, 51-52 